ISSN 0258-7122 (Print), 2408-8293 (Online)

Bangladesh J. Agril. Res. 42(1): 13-25, March 2017

\title{
EFFECT OF LEAF TRICHOMES AND METEOROLOGICAL PARAMETERS ON POPULATION DYNAMICS OF APHID AND JASSID IN COTTON
}

\author{
M. R. AMIN ${ }^{1}$, R. AFRIN ${ }^{2}$, M. Z. $\operatorname{ALAM}^{3}$ \\ M. M. HOSSAIN ${ }^{4}$ AND Y. J. KWON ${ }^{5}$
}

\begin{abstract}
This study was conducted with $\mathrm{CB} 1, \mathrm{CB} 3, \mathrm{CB} 5, \mathrm{CB} 8$ and $\mathrm{C} 12$ cotton varieties to determine the role of leaf trichomes and meteorological factors on the abundances of aphid and jassid. The mean population of the pests on the tested varieties differed significantly and showed negative correlation with trichomes. The pests were most abundant on $\mathrm{CB} 12$, and each variety revealed significantly higher population of jassid than that of aphid. Both the pests built up their population in the juvenile stage of the plants (73 days after sowing) and continued until harvesting. Aphid population was the highest on CB12 in the first week of November, whereas maximum abundance of jassid was on CB12 in the third week of December. Weather parameters were found insignificant on aphid abundance, but jassid population on the varieties was correlated with maximum and minimum temperatures, relative humidity and rainfall. Multiple regression equation based on weather parameters exerted 8.8 - 43.2\% and 54.4 $77.7 \%$ role on population build up of aphid and jassid, respectively. Maximum temperature had the most important effect which contributed $61.2 \%$ population fluctuation of jassid on CB12.
\end{abstract}

Keywords: Abiotic factors, Gossypiun hirsutum, sucking insects.

\section{Introduction}

Twelve species of insects are reported causing damage to cotton, Gossypium hirsutum in Bangladesh. Of them aphid, Aphis gossypii Glover (Hemiptera: Aphididae) and jassid, Amrasca devastans Distant (Hemiptera: Cicadellidae) are the most destructive, and cause damage throughout the season (Amin et al., 2008; Amin et al., 2009; Tithi et al., 2010; Azad et al., 2011). Management of these sucking insects in Bangladesh is mostly relied on synthetic insecticides, which pollute the environment and threats to the abundance and diversity of predator and pollinator species (Azad et al., 2010; Hossain et al., 2013).

The aphid and jassid are sucking insects which ingest cell sap from leaves and developing bolls of cotton and transmit viral diseases. During feeding aphids

\footnotetext{
${ }^{1-3}$ Department of Entomology, Bangabandhu Sheikh Mujibur Rahman Agricultural University (BSMRAU), Gazipur, Bangladesh, ${ }^{4}$ Department of Horticulture, BSMRAU, Gazipur, Bangladesh, ${ }^{5}$ School of Applied Biosciences, Kyungpook National University, Daegu, Korea.
} 
secrete honeydew, which enhances sooty mold development, while jassids inject toxic substance, thus the pest retards photosynthesis, transportation of nutrients and water, and growth of the plants (Bi et al., 2001). The infested plants produce significantly lower amount of yield with degraded quality of fiber that creates problem in lint processing (Sharma and Singh, 2011). Bangladesh is a highly vulnerable country to climate change. The increasing temperature and $\mathrm{CO}_{2}$ gases cause irremediable rainfall and drought that enhances pest problems and reduces the effectiveness of current pest management strategies (Amin et al., 2013). Population fluctuations of herbivore insects throughout the cropping season depend on the amount and daily distribution of rainfall, relative humidity, temperature and sunshine (Jindal and Brar, 2005).

Different host plant species and varieties protect themselves from insect attack either with their chemical substances or morphological structures, which interrupt the life cycle, reproduction and population dynamics of the pests. Cotton varieties with higher densities of leaf trichomes exhibit resistance to insects (Bhat et al., 1984). Cultivation of resistant variety ensures the plant to keep free from insect infestation and exerts higher yield without pest management expenditure (Nault et al., 2004). Information on cotton insect pests associated with the commercial varieties are inadequate in Bangladesh and the relevance of the results in relation to weather conditions is unknown, however, knowledge on varietal susceptibility or resistance, and population dynamics of the pest regarding weather parameters are fundamental components in forecasting model of an integrated pest management program. Considering the damage severity of aphid and jassid on cotton in Bangladesh, this study was designed to know the impact of weather parameters and leaf trichomes on the population dynamics of these two sucking insects on five commercially cultivated varieties.

\section{Materials and Method}

The study was conducted during July 2013 to January 2014 in the research field of the Department of Entomology, Bangabandhu Sheikh Mujibur Rahman Agricultural University (BSMRAU), Gazipur, Bangladesh. The eexperimental location $\left(25^{\circ} 25^{\prime}\right.$ North latitude and $89^{\circ} 5^{\prime}$ East longitude) is surrounded by Sal, Shorea robusta Gaertn forest and characterized by a well-defined dry season (February to May), wet season (June to September) and short winter (December and January).

The commercial cotton varieties CB1, CB3, CB5, CB8 and CB12 released by the Cotton Development Board of Bangladesh were cultivated for this study. The experimental design was randomized complete block with three replications. The plot size was $4.0 \mathrm{~m} \times 4.0 \mathrm{~m}$ and the spacing between block to block and plot to plot was $1.0 \mathrm{~m}$ and $1.0 \mathrm{~m}$, respectively. Seeds were sown on $2^{\text {nd }}$ July 2013 in rows apart from $50 \mathrm{~cm}$ plant to plant and $1.0 \mathrm{~m}$ from row to row. All agronomic 
practices except pest control were adopted time to time to successfully raise the crops.

To observe the population abundance of aphid and jassid on the tested varieties, field inspection was done weekly from emergence of seedlings to first harvest of the seed cotton. For the counts of aphid and jassid population, three plants were randomly selected from each plot and tagged. The leaves of the plants were observed in such a way that one leaf of the upper part of the first plant, one leaf of the middle part of the second plant and one leaf of the bottom part of the third plant of each variety were taken into account. Both aphid and jassid built up their population in the second week of September (73 day after sowing, DAS) i. e., at the blooming stage of the plants and data collection was started from 75 DAS. The population of aphid and jassid were counted with the help of a magnifying glass (FD75, Ballon Brand, China). Meteorological data related to temperature, relative humidity and rainfall were recorded from the adjoining meteorological observatory section of BSMRAU.

An analysis of variance (ANOVA) with Duncan's Multiple Range Test (DMRT) was applied to compare the population abundance of aphid and jassid on the cotton varieties. Comparison between aphid and jassid population on each variety was made with Student's T test. The Pearson's correlation was used to examine the relationship between trichome number and the pest population. The effects of weather parameters on the population abundance of aphid and jassid on the cotton varieties were determined by working out simple correlation. The combined effect of the maximum and minimum temperature, relative humidity and rainfall on the population abundance of the insects were measured by using a Multiple Linear Regression Equation. All the analyses were performed using IBM SPSS statistics 21 .

\section{Results and Discussion}

\section{A. Results}

Mean abundance of aphid and jassid on the cotton varieties (Fig. 1) ranged from $4.3 \pm 0.4$ to $6.4 \pm 0.7$ and $7.3 \pm 0.6$ to $13.1 \pm 1.1$ leaf $^{1}$, respectively and the results differed significantly (aphid: $F_{4,250}=2.9, p<0.05$; jassid: $F_{4,250}=9.9, p<$ 0.001 ). Among the tested varieties, CB12 revealed significantly higher number of aphid and jassid population compared to other varieties. T statistics demonstrated significantly higher abundance of jassid than aphid on each variety $\left(\mathrm{t}_{50}=4.7, \mathrm{p}<\right.$ $0.001 ; \mathrm{t}_{50}=5.7, \mathrm{p}<0.001 ; \mathrm{t}_{50}=4.8, \mathrm{p}<0.001 ; \mathrm{t}_{50}=3.2, \mathrm{p}<0.01 ; \mathrm{t}_{50}=4.9, \mathrm{p}<$ 0.001 for $\mathrm{CB} 1, \mathrm{CB} 3, \mathrm{CB} 5, \mathrm{CB} 8$ and $\mathrm{CB} 12$, respectively).

Number of trichomes on the midrib of the varieties showed significant negative correlation $\left(\mathrm{y}=-0.050 \mathrm{x}+7.607, \mathrm{r}=0.904, \mathrm{~F}_{1,3}=13.0, \mathrm{p}<0.05\right)$ with aphid, and non-significant negative correlation $\left(y=-0.107 x+14.57, r=0.684, F_{1,3}=2.6, p\right.$ $=0.20$ ) with jassid population (Fig. 2). 




Fig. 1. Abundance (mean \pm SE) of aphid ( $\square$ ) and jassid ( $\square$ ) population on five cotton varieties. Bars with same letter are not significantly different (DMRT, $p \leq 0.05$ ).

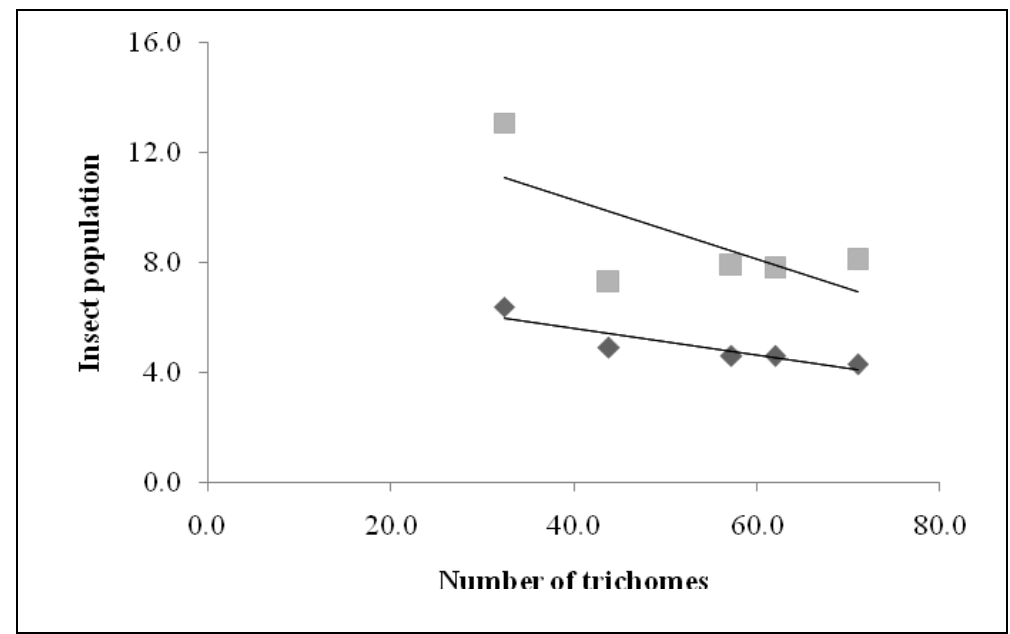

Fig. 2. Relationship between insect population (aphid $\square$ and jassid $\square$ ) and number of trichomes on ventral midrib of the five cotton varieties.

Figure 3 showed the population abundance of aphid throughout the season on the tested varieties. An increased trend of population was observed in the first week of November on all the varieties and then declined. At that time, aphid population reached to the peak (17.0 leaf ${ }^{1}$ ) on $\mathrm{CB} 12$ followed by CB3, CB8, CB5 and CB1. Again aphid population increased rapidly in early December and reached the highest (15.0 leaf ${ }^{1}$ ) on CB12 followed by CB1, CB3, CB8 and CB5. After that, aphid population declined rapidly and again increased in early January 
and showed higher density (12.3 leaf $\left.{ }^{1}\right)$ on CB12 followed by CB8, CB1, CB5 and CB3.

Jassid population abundance throughout the season on the tested varieties showed fluctuations (Fig. 4). It increased in the second week of November and then declined. At that time, jassid showed the highest density (22.7 leaf ${ }^{1}$ ) on CB12 followed by CB8, CB5, CB1 and CB3. Jassid population increased rapidly and reached to the peak (26.3 leaf ${ }^{1}$ ) after second week of December on CB12. After this peak, its population declined rapidly and again increased in early January and showed higher density (19.7 leaf ${ }^{1}$ ) on CB12.

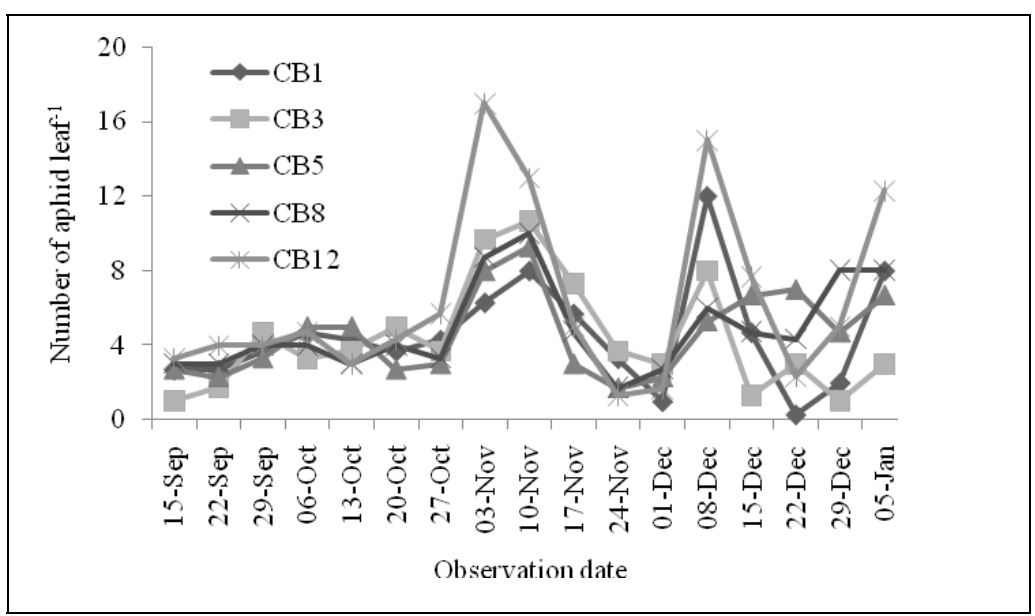

Fig. 3. Population build up of aphid on five cotton varieties.

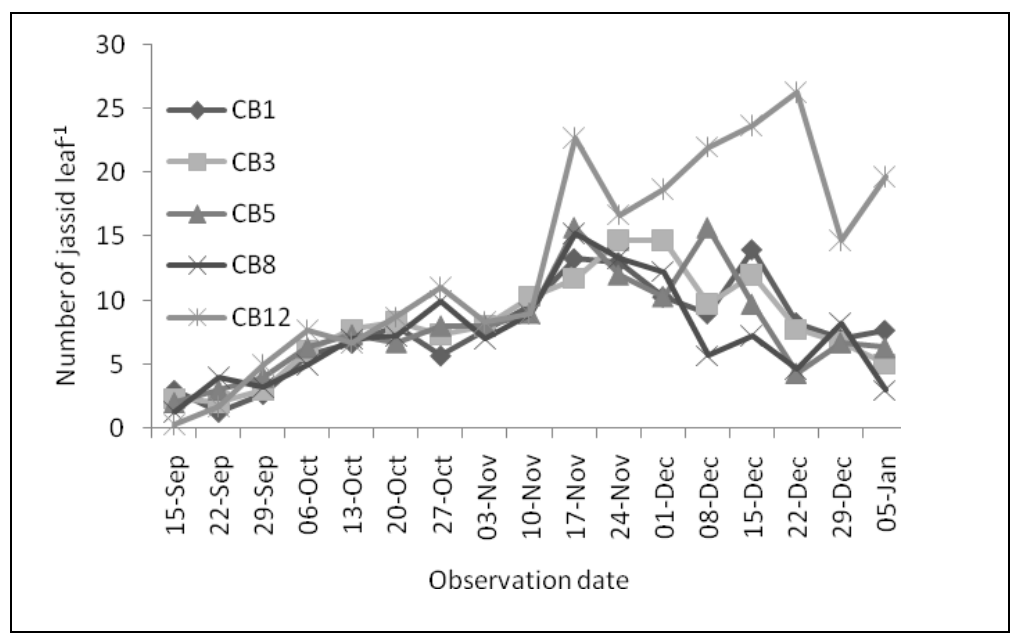

Fig. 4. Population build up of jassid on five cotton varieties. 
The weather parameters indicated that in the middle of September when aphid and jassid population were first recorded, the maximum and minimum temperatures were $32.3{ }^{\circ} \mathrm{C}$ and $26.0{ }^{\circ} \mathrm{C}$, respectively. At that time relative humidity was $85 \%$, and there was no rainfall (Table 1). At the end of October when aphid population started rising, the maximum and minimum temperatures decreased $\left(25.0{ }^{\circ} \mathrm{C}\right.$ and $21.5{ }^{\circ} \mathrm{C}$, respectively), the relative humidity slightly declined $(77 \%)$, and there was little rainfall $(1.1 \mathrm{~mm})$. The peak of aphid population was recorded in the first week of November and at that time maximum and minimum temperatures, relative humidity were $30.0{ }^{\circ} \mathrm{C}, 21.0{ }^{\circ} \mathrm{C}$ and $84 \%$ respectively, and there was no rainfall.

Table 1. Data regarding meteorological observations on various weather parameters

\begin{tabular}{l|c|c|c|c}
\hline \multirow{2}{*}{$\begin{array}{c}\text { Observation } \\
\text { date }\end{array}$} & \multicolumn{2}{|c|}{ Temperature ${ }^{\circ} \mathrm{C}$} & \multirow{2}{*}{$\begin{array}{c}\text { Relative } \\
\text { humidity }\end{array}$} & $\begin{array}{c}\text { Rainfall } \\
(\mathrm{mm})\end{array}$ \\
\cline { 2 - 3 } & Maximum & Minimum & 85 & 0.0 \\
\hline 15.09 .13 & 32.3 & 26.0 & 76 & 0.0 \\
22.09 .13 & 33.5 & 27.5 & 85 & 1.6 \\
29.09 .13 & 32.0 & 26.0 & 92 & 12.9 \\
06.10 .13 & 30.0 & 25.0 & 77 & 0.0 \\
13.10 .13 & 34.0 & 29.0 & 92 & 0.0 \\
20.10 .13 & 32.0 & 26.0 & 77 & 1.1 \\
27.10 .13 & 25.0 & 21.5 & 84 & 0.0 \\
03.11 .13 & 30.0 & 21.0 & 84 & 0.0 \\
10.11 .13 & 30.8 & 16.0 & 73 & 0.0 \\
17.11 .13 & 29.0 & 14.0 & 68 & 0.0 \\
24.11 .13 & 28.2 & 13.5 & 75 & 0.0 \\
01.12 .13 & 29.0 & 15.0 & 75 & 0.0 \\
08.12 .13 & 24.0 & 14.0 & 73 & 0.0 \\
15.12 .13 & 24.0 & 11.5 & 90 & 0.0 \\
22.12 .13 & 25.0 & 13.0 & 89 & 0.0 \\
29.12 .13 & 25.0 & 11.0 & 90 & 0.0 \\
05.01 .14 & 22.0 & 11.0 & \\
\hline
\end{tabular}

Table 2. Correlation coefficient (r) values between aphid population on five cotton varieties and weather parameters

\begin{tabular}{|c|c|c|c|c|}
\hline \multirow{2}{*}{ Variety } & \multicolumn{2}{|c|}{ Temperature ${ }^{\circ} \mathrm{C}$} & \multirow{2}{*}{$\begin{array}{c}\text { Relative humidity } \\
(\%)\end{array}$} & \multirow{2}{*}{$\begin{array}{l}\text { Rainfall } \\
(\mathrm{mm})\end{array}$} \\
\hline & Maximum & Minimum & & \\
\hline CB1 & $-0.266 \mathrm{NS}$ & $-0.181 \mathrm{NS}$ & $-0.105 \mathrm{NS}$ & $0.002 \mathrm{NS}$ \\
\hline CB3 & $0.118 \mathrm{NS}$ & $-0.056 \mathrm{NS}$ & $-0.051 \mathrm{NS}$ & $-0.092 \mathrm{NS}$ \\
\hline CB5 & - $0.308 \mathrm{NS}$ & $-0.328 \mathrm{NS}$ & $0.344 \mathrm{NS}$ & $0.008 \mathrm{NS}$ \\
\hline CB8 & $-0.313 \mathrm{NS}$ & - $0.399 \mathrm{NS}$ & $0.401 \mathrm{NS}$ & $-0.122 \mathrm{NS}$ \\
\hline CB12 & $-0.319 \mathrm{NS}$ & $-0.252 \mathrm{NS}$ & $0.109 \mathrm{NS}$ & $-0.111 \mathrm{NS}$ \\
\hline
\end{tabular}

NS, Non-significant $(p \leq 0.05)$. 


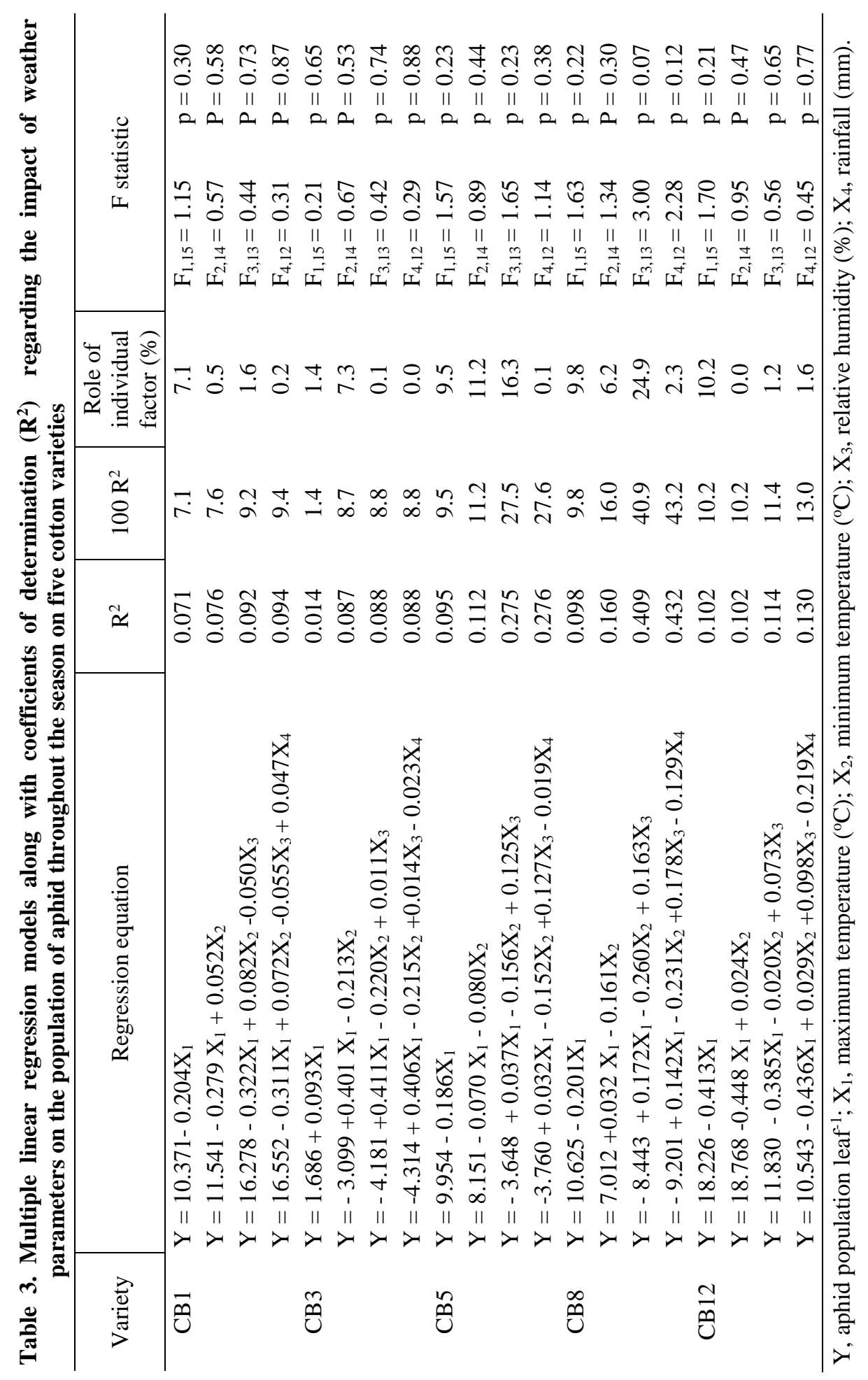


Jassid population started increasing after second week of November when daily maximum and minimum temperatures, and relative humidity were $29.0{ }^{\circ} \mathrm{C}, 14.0$ ${ }^{\circ} \mathrm{C}$ and $73 \%$, and there was no rainfall (Table 1). Jassid population appeared to the peak in the third week of December when the maximum and minimum temperatures, and relative humidity were $25.0^{\circ} \mathrm{C}, 13.0^{\circ} \mathrm{C}$ and $90 \%$, respectively and there was no rainfall.

The correlation coefficient values between aphid population and weather parameters exerted that population on $\mathrm{CB} 3$ had non-significant positive relationship with maximum temperature, whereas other varieties revealed nonsignificant negative relationship (Table 2). Multiple linear regressions demonstrated that maximum temperature individually contributed $1.4-10.2 \%$ aphid population fluctuation among the tested varieties and the effects were nonsignificant (Table 3). Minimum temperature exerted non-significant negative correlation with aphid population on each variety (Table 2) and its individual contribution on population fluctuation among the varieties ranged from 0.0 $11.2 \%$ (Table 3 ), and the effects were non-significant.

The relative humidity revealed non-significant negative correlation with aphid population on $\mathrm{CB} 1$ and $\mathrm{CB} 3$, and non-significant positive correlation on CB5, CB8 and CB12 (Table 2). The relative humidity individually contributed 0.1 $24.9 \%$ population fluctuation among the varieties and its effect was nonsignificant (Table 3). Rainfall showed non-significant positive correlation with aphid population on CB3 and CB5, and other varieties revealed non-significant negative correlation (Table 2). Multiple regression analysis indicated that rainfall individually exerted $0.0-2.3 \%$ contribution towards the population fluctuation of aphid on the varieties and its effect was insignificant (Table 3).

The multiple linear regression analysis showed that all the weather parameters together contributed $43.2 \%$ population fluctuation of aphid on CB8 followed by $27.6 \%, 13.0 \%, 9.4 \%$ and $8.8 \%$ on $\mathrm{CB} 5, \mathrm{CB} 12, \mathrm{CB} 1$ and $\mathrm{CB} 3$, respectively, but none of the equation was found to be significant (Table 3).

Table 4. Correlation coefficient (r) values between jassid population on five cotton varieties and weather parameters

\begin{tabular}{c|l|c|c|c}
\hline \multirow{2}{*}{ Variety } & \multicolumn{2}{|c|}{ Temperature ${ }^{\circ} \mathrm{C}$} & \multirow{2}{*}{$\begin{array}{c}\text { Relative } \\
\text { humidity } \\
(\%)\end{array}$} & $\begin{array}{c}\text { Rainfall } \\
(\mathrm{mm})\end{array}$ \\
\cline { 2 - 3 } & Maximum & Minimum & -0.442 & -0.210 \\
\hline CB1 & -0.437 & $-0.716^{* *}$ & $-0.552^{*}$ & -0.185 \\
CB3 & -0.271 & $-0.573^{*}$ & $-0.601^{*}$ & -0.141 \\
CB5 & -0.344 & $-0.528^{*}$ & $-0.579 *$ & -0.173 \\
CB8 & -0.083 & -0.391 & -0.234 & -0.211 \\
CB12 & $-0.782 * *$ & $-0.863^{* *}$ & \\
\hline
\end{tabular}

* Significant $(\mathrm{p} \leq 0.05), * *$ Highly significant $(\mathrm{p} \leq 0.01)$. 


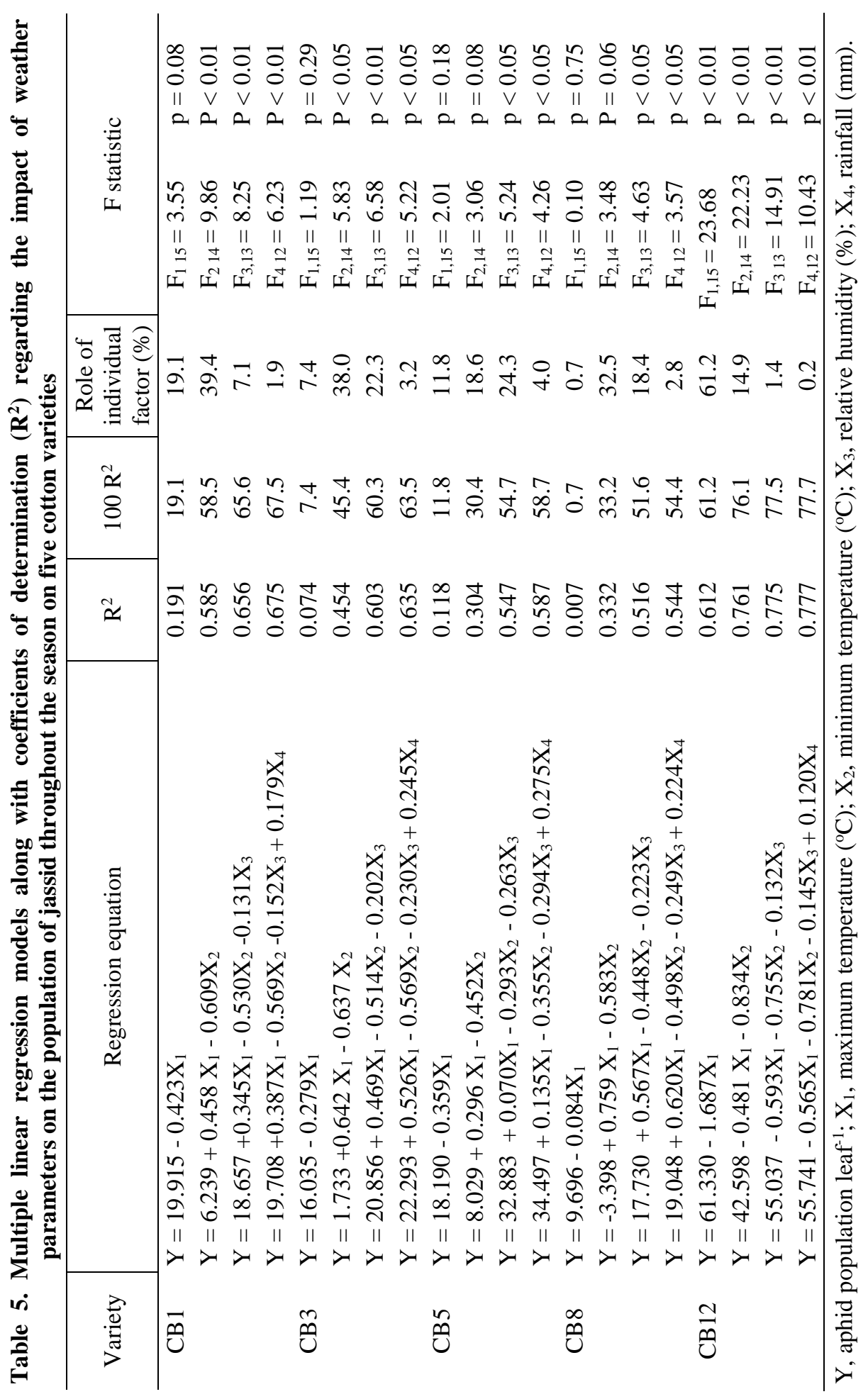


Jassid population on each variety showed negative correlation with weather parameters (Table 4). Maximum temperature individually exerted $0.7-61.2 \%$ population fluctuation among the tested varieties and its effect was highly significant only on the CB12 (Table 5). Minimum temperature individually exerted 14.9 - 39.4\% population fluctuation and its effect was highly significant on all varieties except CB8. The combination effect of maximum and minimum temperature was found to be significant on CB1, CB3 and CB12.

The individual effect of the relative humidity revealed $1.4-24.3 \%$ fluctuation of jassid population and its effect was significant on CB3, CB5 and CB8 (Table 4). The combination effect of maximum and minimum temperature and relative humidity was significant on all varieties. Contribution of rainfall regarding population fluctuation of jassid among the tested varieties varied from $0.2-4.0 \%$ and its effect on each variety was insignificant (Table 5).

The multiple linear regression analysis showed that all the weather parameters together contributed $77.7,67.5,63.5,58.7$ and $54.4 \%$ population fluctuation of jassid on $\mathrm{CB} 12, \mathrm{CB} 1, \mathrm{CB} 3, \mathrm{CB} 5$ and $\mathrm{CB} 8$ variety, respectively, and the equations were significant (Table 5).

\section{B. Discussion}

Aphid and jassid population on the tested varieties differed significantly, and both the species showed significantly higher abundance on CB12. The differences in abundance of the pests on the tested varieties may be due to the leaf trichomes. Other characteristics, such as leaf thickness and toughness, the $\mathrm{pH}$ of the cell sap, content of moisture, sugar, protein, minerals or tanin in the leaf may affect the population abundance. The present study showed close conformity with Amjad et al. (2009) who tested five cotton cultivars against whitefly, thrips, jassid and aphid, and found significant variations in population abundance of the pests on different varieties. The present findings also showed congruity with Khan (2011) who studied jassid, thrips and white fly population on nine cotton varieties and found significant variations in their abundance.

This study showed that the leaf trichomes of the varieties had significant negative correlation with aphid and non-significant negative correlation with jassid and the varieties exerted significantly higher abundance of jassid compared to aphid. The trichomes created obstacles in foraging, feeding, ingestion, digestion, mating and oviposition, thus prevented their abundance.

The emergence of aphid and jassid population was associated with juvenile stage of the plants. Variations in weather conditions and time of the season also have affected population dynamics of the pests. Amjad et. al. (2009) observed the population abundance of sucking insects on five cotton cultivars and found significant variations in population abundance with time of the season. The 
population of aphid and jassid built up on the cotton varieties in the middle of September and continued throughout the season. Shivanna et al. (2011) found the abundance of aphid on cotton throughout the season except July, August and September when the rainfall was very high. In this study, both aphid and jassid population were found the highest on CB12 in the first week of November and in the third week of December, respectively. The meteorological conditions of those periods may be attributed to the enhanced rate of development and reproduction of the pests on cotton crops.

The individual and combine effect of the weather parameters showed nonsignificant effect on the population dynamics of aphid, however the combined effect of the parameters resulted 8.8 to $43.2 \%$ fluctuation. A study by Mahmood et al. (1990) in Pakistan showed that the weather parameters together were responsible for $73.0 \%$ population fluctuation of aphid on okra plants. A study by Sharma et al. (2013) dipicted that aphid population on tomato was positively but non-significantly correlated with the maximum temperature, negative nonsignificant with relative humidity and rainfall.

The maximum and minimum temperatures, relative humidity and rainfall showed significant negative correlation on the population of jassid on the varieties. The weather parameters together also contributed significant effect on the population which varied from 54.4 to $77.7 \%$. Sharma and Singh (2012) noted 50.0 to $96.0 \%$ population fluctuation of jassid on five varieties of potato in Uttar Pradesh, India. Our findings are in line with Patel et al. (1997), who reported a negative correlation between the population of jassid and temperature. The present findings are partially in accordance with those of Arif et al. (2006), who reported a negative and non-significant correlation between the relative humidity and jassid-population on okra. Prasad and Logiswaran (1997) found a negative association between the jassid population and rainfall.

Understanding the demographic parameters of a pest regarding meteorological parameters, it is essential to develop an integrated pest management strategy for crop varieties, because these parameters provide population growth rate of an insect pest in the current and next generations (Frel et. al., 2003). The present experiment demonstrated significant differences in the abundance of two sucking insects among the five cotton varieties tested. The lower population abundance of aphid and jassid on CB1 and CB3 was due to higher number of trichomes.

\section{References}

Amin, M. R., D. A. Tithi, H. M. S. Azad and S. M. A. Hossain. 2009. Field evaluation of neemazol and pyrethroid for management of cotton bollworm. Bangladesh $J$. Environ. Sci. 16:139-142.

Amin, M. R., H. M. S. Azad, S. M. A. Hossain and D. A. Tithi 2013. Pest, predator and pollinator abundance in the cotton field of Bangladesh: A climate change country. 
In: Sundaresan, J., S. Sreekesh, A. L. Ramanathan, L. Sonnenschein and R. Boojh (eds) Climate change and environment. pp.100-106. Scientific Publishers, India.

Amin, M. R., M. A. Ahad, M. H. Hossain, S. M. A. Hossain and D. A. Tithi. 2008. Characteristics of some cotton varieties in relation to seasonal abundance of pests, predators and their impact on yield and quality. J. Agrof. Environ. 2: 67-70.

Amjad, M., M. H. Bashir and M. Afzal. 2009. Comparative resistance of some cotton cultivars against sucking insect pests. Pak. J. Soc. Life Sci. 7: 144-147.

Arif, M. J., M. D. Gogi, M. Mirza, K. Zia and F. Hafeez. 2006. Influence of plant spacing and abiotic factors on population dynamics of sucking insect pests of cotton. Pak. J. Biol. Sci. 9: 1364-1369.

Azad, H. M. S., M. R. Amin, D. A. Tithi and S. M. A. Hossain. 2011. Performances of three cotton varieties cultivated under economic threshold level based insecticide sprayed and non-sprayed conditions. Our Nature. 9:21-25.

Azad, H. M. S., M. R. Amin, S. M. A. Hossain and D. A. Tithi. 2010. Field abundance and incidence of predator associated with different cotton varieties at Dinajpur in Bangladesh. $J$. Environ. Sci. Nat. Resources. 3: 127-130.

Bhat, M.G., A.B. Joshi and M. Singh. 1984. Relative loss of seed cotton yield by jassid and bollworms in some cotton genotypes (Gossypium hirsutum L.). Indian J. Entomol. 46: 165-173.

Bi, J. L., G. R. Ballmer, D. L. Hendrix, T. J. Henneberry and N. C. Toscano. 2001. Effect of nitrogen fertilizer on cotton whitefly Bemisia argentifolii populations and honeydew production. Ent. Exp. Appl. 99: 25-36.

Frel, A., H. Gu, C. Cardona and S. Dorn. 2003. Antixenosis and antibiosis of common beans to Thrips palmi. J. Econ. Entomol. 93: 1577-1584.

Hossain, S. M. A., M. A. Baque and M. R. Amin. 2013. Comparative effectiveness of seed treating and foliar insecticides against sucking pests of cotton and impact on their natural enemies. Bangladesh J. Agril. Res. 38: 61-70.

Jindal, J. and D. S. Barar. 2005. Population dynamics of sucking pests on Hirsutum cotton hybrids in relation to weather factors. Indian J. Ecol. 32: 58-60.

Khan, S. M. 2011. Varietal performance and chemical control used as tactics against sucking insect pests of cotton. Sarhad J. Agric. 27: 255-261.

Mahmood, T., K. M. Khokhar, M. Banaras and M. Ashraf. 1990. Effect of environmental factors on the density of leaf hopper, Amrasca devastans (Distant) on okra. Trop. Pest Manag. 36: 282-284.

Nault, B. A., A. G. Taylor, M. Urwiler, T. Rabaey and W. D. Hutchison. 2004. Neonicotiniod seed treatments for managing potato leafhopper infestations in snap bean. Crop Protection. 23: 147-154.

Patel, K. I., J. R. Patel, D. B. Jayani, A. M. Shekh and N. C. Patel. 1997. Effect of seasonal weather on incidence and development of major pests of okra (Abelmoschus esculentus). Indian J. Agril. Sci. 67: 181-183. 
Prasad, S. G. and G. Logiswaran. 1997. Influence of weather factors on population fluctuation of insect pest of brinjal at Madurai, Tamilnadu, India. Indian J. Entomol. 59: $385-388$.

Sharma, D., A. Maqbool, H. Ahmad, K. Srivastava, M. Kumar, V. Vir and S. Jamwal. 2013. Effect of meteorological factors on the population dynamics of insect pests of tomato. Vegetable Sci. 40: 90-92.

Sharma, V. and B. P. Singh. 2011. Effect of pest infestation on processing attributes of potato in early crop season. Potato J. 38: 113-120.

Sharma, V. and B. P. Singh. 2012. Effect of varieties, seasons and weather on population buildup of leaf hopper (Amrasca devastans Distant) on potato crop. Potato J. 39: 23-30.

Shivanna, B. K., N. K. Gangadhara, M. K. Basavaraja, R. Nagaraja, S. C. M. Kalleswara and C. Karegowda. 2011. Impact of abiotic factors on population dynamics of sucking pests in transgenic cotton ecosystem. Intl. J. Sci. Nat. 2: 72-74.

Tithi, D. A., M. R. Amin, S. M. A. Hossain and H. M. S. Azad. 2010. Consequence of Spodoptera litura Fabricius (Lepidoptera: Noctuidae) morphometrics reared on different cotton varieties. Our Nature. 8: 118-121. 
